\title{
Diagnostic and therapeutic considerations in Turner syndrome
}

\section{Seung Yang, MD, PhD}

Department of Pediatrics, Kangdong Sacred Heart Hospital, Hallym University College of Medicine, Seoul, Korea
Received: 18 September, 2017

Revised: 21 November, 2017

Accepted: 10 December, 2017

Address for correspondence:

Seung Yang, MD, PhD

Department of Pediatrics, Kangdong

Sacred Heart Hospital, Hallym University College of Medicine, 150 Seongan-ro, Gangdong-gu, Seoul 05355, Korea

Tel: +82-2-2224-2251

Fax: +82-2-482-8334

E-mail: drsyang@hallym.or.kr

https://orcid.org/0000-0002-3380-

6962
Newly developed genetic techniques can reveal mosaicism in individuals diagnosed with monosomy $X$. Noninvasive prenatal diagnosis using maternal blood can detect most fetuses with $X$ chromosome abnormalities. Low-dose and ultralow-dose estrogen replacement therapy can achieve a more physiological endocrine milieu. However, many complicated and controversial issues with such treatment remain. Therefore, lifetime observation, long-term studies of health problems, and optimal therapeutic plans are needed for women with Turner syndrome. In this review, we discuss several diagnostic trials using recently developed genetic techniques and studies of physiological hormone replacement treatment over the last 5 years.

\section{Keywords: Turner syndrome, Diagnosis, Hormone replacement therapy}

\section{Introduction}

Six cases of a syndrome of infantilism, congenital webbed neck, and cubitus valgus were first reported by Turner in 1938. There was a definite genital change in 2 cases following administration of anterior pituitary gonadotropic hormone ${ }^{1)}$. Around 20 years later, this socalled Turner syndrome (TS) was identified as X chromosome monosomy ${ }^{2}$. The phenotype of this syndrome was described as follows: short stature, broad chest, congenital lymphedema, low posterior hairline, prominent ears, narrow and acutely arched palate, abnormal fingernails, lack of pubertal onset by adolescence, presence of streak ovaries, normal intelligence ${ }^{3)}$. The most common ages at which females present with TS include the newborn period, when they present with lymphedema or cardiac anomalies; school age, when they present with short stature; and adolescence, when they present with a lack of pubertal onset.

Recently developed genetic techniques can reveal mosaicism in individuals diagnosed with monosomy X. Additionally, noninvasive prenatal diagnosis using maternal blood can detect most cases of $\mathrm{X}$ chromosome abnormalities ${ }^{4)}$. This review included diagnostic issues and hormone replacement therapy as therapeutic issues. We firstly introduced several diagnostic trials using newly developed genetic techniques. Then, we reviewed recent studies on hormone replacement therapy for optimal growth and puberty for patients with TS from the last 5 years. The fertility issue, neurocognitive issue, cardiovascular health issues, and health surveillance for comorbidities throughout the lifespan were not included in this review.

\section{Diagnostic considerations}

\section{Genotype and phenotype}

The birth incidence of TS is 1 in 2,000-2,500 live-born girls. Monosomy X underlies 50\% of cases, and the others have mosaicism. There is a known poor genotype-phenotype correlation in $\mathrm{TS}^{5-7)}$. This may be due to heterogeneity in tissue mosaicism, which also makes TS difficult to diagnose. When the length and weight of neonates with TS are compared among different 
karyotypes at birth, there is no effect of karyotype on height in girls with TS, whereas weight is greater in girls with $46, \mathrm{X}, \mathrm{i}(\mathrm{Xq})$ and $45, \mathrm{X} / 46, \mathrm{X}, \mathrm{i}(\mathrm{Xq})$ karyotypes $^{8}$. For early diagnosis, population-based, validated cutoff values for height-for-age, height distance from target height, and changes in growth rate were suggested, with $97 \%$ sensitivity and $96 \%$ specificity in all girls with TS. However, this method is so complicated that computerized analysis is required for practical use ${ }^{9}$. Short-arm $\mathrm{X}$ chromosome deletion causes many phenotypes, whereas longarm deletion, particularly the loss of Xq26-Xq28, is significantly related to abnormal ovarian function without characteristic Turner features ${ }^{10)}$.

\section{Noninvasive prenatal test}

Whole-genome sequencing of circulating cell-free DNA in maternal plasma has enabled noninvasive prenatal testing for common autosomal aneuploidies, including TS $(45, \mathrm{X})$. However, the incidence of mosaicism may complicate noninvasive prenatal testing, particularly with respect to gonadal dysgenesis in the adult female population. In one study, the combined sensitivity for detecting sex chromosome aneuploidies was $96.2 \%$, the false positive rate was $0.3 \%$, and the nonreportable rate was $5 \%{ }^{11)}$. In another report, which excluded mosaic samples, the results corresponded to a sensitivity of $100 \%$ and a specificity of $99.75 \%$ for detecting sex chromosome aneuploidies ${ }^{12)}$. This method may miss structurally abnormal $\mathrm{X}$ chromosome and mosaicism.

\section{Real-time polymerase chain reaction}

Real-time polymerase chain reaction (PCR) gene quantification can be used for diagnosis of $\mathrm{TS}^{13,14)}$. Correa et al. ${ }^{14)}$ proposed an algorithm for neonatal TS detection using 2 study genes and one normalizing gene, ARSE (arylsulfatase E-OMIM 300180), MAGEH1 (melanoma antigen, H1-OMIM protein: 300548), and $H B B$ (beta hemoglobin, OMIM OMIM 141900), which are located in the telomeric pseudoautosomal region (ARSEXp22.3), the pericentromeric region (MAGEH1-Xp11.21), and on the autosomal chromosome (HBB-11p15.5), respectively. $A R S E / H B B$ and $M A G E H 1 / H B B$ ratios less than 0.81 and 1.24 , respectively, confirm a diagnosis of TS.

\section{Single nucleotide polymorphism arrays}

Single nucleotide polymorphism (SNP) array genotyping can provide superior resolution in comparison to metaphase karyotype analysis. Cytogenetic analysis by karyotyping is too labor intensive for rapid population-based screening and may fail to detect small fragments of $Y$ chromosome material. Prakash et al ${ }^{15}$ ) showed that SNP array genotyping is a feasible alternative to karyotype testing in diagnosing TS, particularly for detecting cryptic $\mathrm{Y}$ chromosomes. However, using arrays led to incorrect interpretation of rare cell lines that were present in fewer than 5\% of sampled cells. Additionally, karyotyping retains an important advantage over arrays for identifying complex mosaicism, including translocations and rare $\mathrm{X}$ chromosome structural variants. SNP genotyping is incapable of detecting fully balanced X chromosome translocations.

\section{Detection for cryptic mosaics}

One meta-analysis ${ }^{16)}$ questioned whether pure monosomy X occurs. Although 45,X, the characteristic karyotype associated with TS, is the only viable monosomy in humans, only around $1 \%$ of conceptuses recognized with this karyotype survive until live birth. The authors suggested a "rescue line" as one with a viable karyotype(s), the presence of which enables the survival of a putative nonmosaic aneuploid embryo to live birth. In this regard, they arrived at some hypotheses: that all $45, \mathrm{X}$ individuals with TS are cryptic mosaics, the absence of the $\mathrm{X}$ chromosome in 45 , $\mathrm{X}$ embryos is primarily caused by mitotic factors, and the placenta is a strong candidate for the location of the rescue line in apparently nonmosaic $45, \mathrm{X}$ individuals. More efforts are needed to identify cryptic mosaic 45 ,X TS patients by counting more cells during karyotype analysis, examining additional tissues, and using SNP microarrays, fluorescence in situ hybridization, and PCR methods.

Therapeutic considerations: focus on hormone replacement therapy for growth and puberty

\section{Growth hormone}

Skeletal disproportion in TS includes the following phenotypes: micrognathia, high-arched palate, short fourth metacarpals, genu valgum, Madelung wrist deformities, and short limbs. Short stature, recognized by Lemli and Smith ${ }^{3)}$ as a ubiquitous abnormality, is now effectively treated with early initiation of recombinant growth hormone $(\mathrm{GH})$ therapy ${ }^{17-19}$. Achieving as normal a height as possible through GH therapy has become standard ${ }^{20)}$. Several growth references (including one from the World Health Organization) for TS have been published and reviewed ${ }^{21-23)}$. Homeobox-containing gene SHOX haploinsufficiency has been well established as causing a wide spectrum of short stature phenotypes in patients with $\mathrm{TS}^{24)}$. Other pathophysiological pathways not involving SHOX may affect both fetal and postnatal growth, and response to $\mathrm{GH}$ in $\mathrm{TS}^{25)}$. The sitting height/height standard deviation score tends to improve with age in TS patients, and is inversely correlated with age at puberty onset. This phenomenon may be explained by the low exposure of growth cartilage to estrogens and the relatively late start of exogenous estrogens in most girls with TS, which protects them from early epiphyseal closure and may therefore attenuate body disproportion, allowing for a longer period of limb growth, in comparison to girls with isolated SHOX defects ${ }^{26}$. As short stature in SHOX deficiency and TS share a similar etiology, GH replacement therapy shows 
similar efficacy i0n both disorders ${ }^{18}$. A large-scale study in Japan showed that GH treatment was effective for increasing the height of children with GH deficiency or $\mathrm{TS}^{27}$. Individual sensitivity to recombinant human $\mathrm{GH}$ is known to be variable ${ }^{28)}$. $\mathrm{GH}$ induces significant growth acceleration during the first year, but the response wanes over time ${ }^{18,19,27)}$. Specific growthrelated genetic markers are associated with growth response in $\mathrm{TS}^{29,30)}$. Tyrosine-protein phosphatase nonreceptor type 1 (PTPN1; rs2038526) and estrogen receptor alpha (ESR1; rs2347887 and rs6927072) were shown to influence height velocity in $\mathrm{TS}^{30}$. Homozygosity for the suppressor of cytokine signaling 2 (SOCS-2; rs3782415) T allele, the growth hormone receptor $(G H R)$ exon 3 full-length allele, and/or the -202 locus of the insulin-like growth factor binding protein 3 promoter region (rs2854744) C allele were related to a low response to $\mathrm{GH}$ replacement therapy in $\mathrm{TS}^{31}$. These results suggest that a pharmacogenomic approach of individualized plans for GH replacement therapy should be considered in TS patients. Schrier et al. ${ }^{32}$ suggested that dosing GH per body surface area $\left(\mathrm{m}^{2}\right)$ is as efficacious as dosing per body weight $(\mathrm{kg})$, and is more cost-effective. Long-term GH therapy has a positive influence on craniofacial development in TS girls, with the greatest impact on posterior facial height and mandibular ramus ${ }^{33}$. A lichen planus-like drug reaction associated with GH therapy was reported in a child patient with $\mathrm{TS}^{34}$.

\section{Addition of androgen to $\mathrm{GH}$}

To increase adult height, nonaromatizable androgens such as oxandrolone and stanozolol can be used ${ }^{35-377}$. If a patient is severely short for her age, very short adult height is expected, or growth rate is modest despite $\mathrm{GH}$ use, additive treatment with the anabolic steroid oxandrolone $(0.03-0.05 \mathrm{mg} / \mathrm{kg} /$ day, from the age of 10 years or older) can be considered. Possible adverse events such as virilization (e.g., clitoromegaly, voice deepening, hirsutism and acne), delayed breast development, and decreased HDL cholesterol levels, are not commonly reported at dosages of less than $0.06 \mathrm{mg} / \mathrm{kg} / \mathrm{day}^{36)}$. However, the possibility for the unwanted adverse effects prompts the need for caution in clinical use of androgen ${ }^{38)}$.

\section{Sex hormone replacement; estrogen and progesterone}

Estrogen replacement therapy (ERT) is required to initiate and maintain pubertal development in women with $\mathrm{TS}^{17,20)}$. It is not recommended for girls with spontaneous puberty. Serum anti-Müllerian hormone (AMH) levels are a known sensitive marker of follicular pool in prepubertal girls with TS. A strong relationship was observed between measurable serum AMH and signs of spontaneous puberty, such as breast development and menarche, in $\mathrm{TS}^{39)}$. The goal of ERT is to achieve the physiological endocrine milieu at a tempo consistent with the peer group. Since there is no estrogen patch in Korea so far, oral estrogen therapy is used. To mimic peripubertal estradiol levels
(7-24 pmol/L), a starting dose of 50-70 $\mathrm{ng} / \mathrm{kg} /$ day estradiol is recommended, and for breast development (24-46 pmol/ $\mathrm{L}), 80-120 \mathrm{ng} / \mathrm{kg} / \mathrm{day}$ is recommended ${ }^{40)}$. An ultralow-dose of $25 \mathrm{ng} / \mathrm{kg} /$ day ERT beginning as early as 5 years of age was even recommended, because childhood ERT normalized the onset and tempo of puberty ${ }^{41}$. However, the recently updated guideline from the 2016 Cincinnati International Turner syndrome meeting recommend that estrogen replacement should start between 11 and 12 years of age increasing to adult dosing over $2-3$ years. They suggests to not routinely add very-low-dose estrogen supplementation in the prepubertal years to further promote growth ${ }^{42}$. No differences in body composition, lipid oxidation, or lipid concentrations were observed between transdermal and oral routes of estrogen administration. However, transdermal administration results in a more physiological estrogen milieu than oral administration ${ }^{43}$. Moreover, oral administration may increase the risk of venous thromboembolism more than the transdermal route ${ }^{44)}$. Although individualized dosage protocols may be ideal for puberty induction with low-dose oral estradiol, fixed dosages within a fixed period can be considered to avoid the need to adjust the dose at each visit ${ }^{45)}$. A 5 -year prospective doubleblind randomized controlled clinical trial did not recommend higher estrogen doses in TS girls with increased risk of fractures, because this treatment did not affect bone mineral density or bone markers ${ }^{46)}$. Inducing puberty at a physiologically appropriate age in girls with TS is important because it can improve self-esteem, social adjustment, and initiation of sex life ${ }^{47)}$. The Pediatric Endocrine Society standardized clinical assessment and management plan algorithm for estrogen replacement may be useful ${ }^{48)}$.

Progestin should be added once breakthrough bleeding occurs, or after 2 years of estrogen treatment ${ }^{42}$, which can reduce the risk of endometrial cancer and/or breast cancer related to prolonged unopposed estrogen, although the risk is low in $\mathrm{TS}^{49,50)}$. Progestin can be added for 10 days each month for withdrawal bleeding, and adult women with TS should preferably continue treatment with estrogen in combination with a sequential progesterone.

\section{Conclusion}

There have been marked advances in the diagnosis and treatment of TS since its first description in 1938 by Turner. GH therapy for achieving nearly normal height through and sex hormone replacement therapy for inducing normal pubertal development have become standard therapies. The feasibility of molecular techniques for diagnosis needs to be further established. Since normal height attainment and age-appropriate pubertal development have reported to improve quality of life in young adults with $\mathrm{TS}^{47,511}$, further prospective studies are needed for optimal growth-promoting treatment and puberty-inducing schedule. 


\section{Conflict of interest}

No potential conflict of interest relevant to this article was reported.

\section{References}

1. Turner HH. A syndrome of infantilism, congenital webbed neck, and cubitus valus. Endocrinology. 1938;23:566-74.

2. Ford CE, Jones KW, Polani PE, De Almeida JC, Briggs JH. A sex-chromosome anomaly in a case of gonadal dysgenesis (Turner's syndrome). Lancet 1959;1:711-3.

3. Lemli L, Smith DW. The XO syndrome. A study of the differentiated phenotype in 25 patients. J Pediatr 1963;63:577-88.

4. Levitsky LL, Luria AH, Hayes FJ, Lin AE. Turner syndrome: update on biology and management across the life span. Curr Opin Endocrinol Diabetes Obes 2015;22:65-72.

5. Mohamed S, Roche EF, Hoey HM. Mode of initial presentation and chromosomal abnormalities in Irish patients with Turner syndrome: a single-centre experience. J Pediatr Endocrinol Metab 2015;28:1215-8.

6. Wonkam A, Veigne SW, Abass A, Ngo Um S, Noubiap JJ, Mbanya JC, et al. Features of Turner syndrome among a group of Cameroonian patients. Int J Gynaecol Obstet 2015;129:264-6.

7. Miguel-Neto J, Carvalho AB, Marques-de-Faria AP, GuerraJúnior G, Maciel-Guerra AT. New approach to phenotypic variability and karyotype-phenotype correlation in Turner syndrome. J Pediatr Endocrinol Metab 2016;29:475-9.

8. Sari E, Bereket A, Yeşilkaya E, Baş F, Bundak R, Aydın BK, et al. Anthropometric findings from birth to adulthood and their relation with karyotpye distribution in Turkish girls with Turner syndrome. Am J Med Genet A 2016;170A:9428.

9. Saari A, Sankilampi U, Hannila ML, Saha MT, Mäkitie O, Dunkel L. Screening of turner syndrome with novel auxological criteria facilitates early diagnosis. J Clin Endocrinol Metab 2012;97:E2125-32.

10. Mercer CL, Lachlan K, Karcanias A, Affara N, Huang S, Jacobs PA, et al. Detailed clinical and molecular study of 20 females with Xq deletions with special reference to menstruation and fertility. Eur J Med Genet 2013;56:1-6.

11. Mazloom AR, Džakula Ž, Oeth P, Wang H, Jensen T, Tynan J, et al. Noninvasive prenatal detection of sex chromosomal aneuploidies by sequencing circulating cell-free DNA from maternal plasma. Prenat Diagn 2013;33:591-7.

12. Liang D, Lv W, Wang H, Xu L, Liu J, Li H, et al. Non-invasive prenatal testing of fetal whole chromosome aneuploidy by massively parallel sequencing. Prenat Diagn 2013;33:40915.

13. Castronovo C, Rossetti R, Rusconi D, Recalcati MP, Cacciatore $\mathrm{C}$, Beccaria E, et al. Gene dosage as a relevant mechanism contributing to the determination of ovarian function in Turner syndrome. Hum Reprod 2014;29:368-
79

14. Corrêa SC, Rocha MN, Richeti F, Kochi C, Silva E Lima LA, Magalhães $\mathrm{M}$, et al. Neonatal detection of Turner syndrome by real-time PCR gene quantification of the ARSE and MAGEH1 genes. Genet Mol Res 2014;13:9068-76.

15. Prakash S, Guo D, Maslen CL, Silberbach M, Milewicz D, Bondy CA, et al. Single-nucleotide polymorphism array genotyping is equivalent to metaphase cytogenetics for diagnosis of Turner syndrome. Genet Med 2014;16:53-9.

16. Hook EB, Warburton D. Turner syndrome revisited: review of new data supports the hypothesis that all viable $45, \mathrm{X}$ cases are cryptic mosaics with a rescue cell line, implying an origin by mitotic loss. Hum Genet 2014;133:417-24.

17. Stanescu DE, Gruccio D. 50 Years ago in The Journal of Pediatrics: the XO syndrome: a study of the differential phenotype in 25 patients. J Pediatr 2013;163:1044.

18. Blum WF, Ross JL, Zimmermann AG, Quigley CA, Child CJ, Kalifa G, et al. GH treatment to final height produces similar height gains in patients with SHOX deficiency and Turner syndrome: results of a multicenter trial. J Clin Endocrinol Metab 2013;98:E1383-92.

19. Wasniewska M, Aversa T, Mazzanti L, Guarneri MP, Matarazzo P, De Luca F, et al. Adult height in girls with Turner syndrome treated from before 6 years of age with a fixed per kilogram GH dose. Eur J Endocrinol 2013;169:439-43.

20. Legro RS. Turner syndrome: new insights into an old disorder. Fertil Steril 2012;98:773-4.

21. Lyon AJ, Preece MA, Grant DB. Growth curve for girls with Turner syndrome. Arch Dis Child 1985;60:932-5.

22. Saari A, Sankilampi U, Dunkel L. Multiethnic WHO growth charts may not be optimal in the screening of disorders affecting height: Turner syndrome as a model. JAMA Pediatr 2013;167:194-5.

23. Bertapelli F, Barros-Filho Ade A, Antonio MÂ, Barbeta CJ, de Lemos-Marini SH, Guerra-Junior G. Growth curves for girls with Turner syndrome. Biomed Res Int 2014;2014:687978.

24. Clement-Jones M, Schiller S, Rao E, Blaschke RJ, Zuniga A, Zeller R, et al. The short stature homeobox gene SHOX is involved in skeletal abnormalities in Turner syndrome. Hum Mol Genet 2000;9:695-702.

25. Fiot E, Zenaty D, Boizeau P, Haigneré J, Dos Santos S, Léger J, et al. X-chromosome gene dosage as a determinant of impaired pre and postnatal growth and adult height in Turner syndrome. Eur J Endocrinol 2016;174:281-8.

26. Malaquias AC, Scalco RC, Fontenele EG, Costalonga EF, Baldin AD, Braz AF, et al. The sitting height/height ratio for age in healthy and short individuals and its potential role in selecting short children for SHOX analysis. Horm Res Paediatr 2013;80:449-56.

27. Tai S, Tanaka T, Hasegawa T, Ozono K, Tanaka H, Kanzaki S, et al. An observational study of the effectiveness and safety of growth hormone (Humatrope $\left(^{\circ}\right)$ ) treatment in Japanese children with growth hormone deficiency or Turner syndrome. Endocr J 2013;60:57-64. 
28. Bettendorf M, Inta IM, Doerr HG, Hauffa BP, Mehls O, Ranke MB. Height gain in Ullrich-Turner syndrome after early and late growth hormone treatment start: results from a large retrospective German study and potential basis for an individualized treatment approach. Horm Res Paediatr 2013;80:356-62.

29. Clayton P, Chatelain P, Tatò L, Yoo HW, Ambler GR, Belgorosky A, et al. A pharmacogenomic approach to the treatment of children with GH deficiency or Turner syndrome. Eur J Endocrinol 2013;169:277-89.

30. Stevens A, Murray P, Wojcik J, Raelson J, Koledova E, Chatelain $P$, et al. Validating genetic markers of response to recombinant human growth hormone in children with growth hormone deficiency and Turner syndrome: the PREDICT validation study. Eur J Endocrinol 2016;175:63343.

31. Braz AF, Costalonga EF, Trarbach EB, Scalco RC, Malaquias AC, Guerra-Junior G, et al. Genetic predictors of long-term response to growth hormone (GH) therapy in children with GH deficiency and Turner syndrome: the influence of a SOCS2 polymorphism. J Clin Endocrinol Metab 2014;99:E1808-13.

32. Schrier L, de Kam ML, McKinnon R, Che Bakri A, Oostdijk W, Sas TC, et al. Comparison of body surface area versus weight-based growth hormone dosing for girls with Turner syndrome. Horm Res Paediatr 2014;81:319-30.

33. Juloski J, Dumančić J, Šćepan I, Lauc T, Milašin J, Kaić Z, et al. Growth hormone positive effects on craniofacial complex in Turner syndrome. Arch Oral Biol 2016;71:10-5.

34. Soares MQ, Mendonca EF. Lichen planus-like drug reaction associated with recombinant human growth hormone therapy in a child patient with Turner syndrome. Dermatol Online J 2016 Mar 16;22(3). pii: 13030/qt4k61f5jn.

35. Freriks K, Sas TC, Traas MA, Netea-Maier RT, den Heijer M, Hermus AR, et al. Long-term effects of previous oxandrolone treatment in adult women with Turner syndrome. Eur J Endocrinol 2012;168:91-9.

36. Sas TC, Gault EJ, Bardsley MZ, Menke LA, Freriks K, Perry RJ, et al. Safety and efficacy of oxandrolone in growth hormone-treated girls with Turner syndrome: evidence from recent studies and recommendations for use. Horm Res Paediatr 2014;81:289-97.

37. Xiong H, Chen HS, Du ML, Li YH, Ma HM, Su Z, et al. Therapeutic effects of growth hormone combined with low-dose stanozolol on growth velocity and final height of girls with Turner syndrome. Clin Endocrinol (Oxf) 2015;83:223-8.

38. Menke LA, Sas TC, de Muinck Keizer-Schrama SM, Zandwijken GR, de Ridder MA, Odink RJ, et al. Efficacy and safety of oxandrolone in growth hormone-treated girls with turner syndrome. J Clin Endocrinol Metab 2010;95:1151-60.

39. Visser JA, Hokken-Koelega AC, Zandwijken GR, Limacher A, Ranke MB, Flück CE. Anti-Müllerian hormone levels in girls and adolescents with Turner syndrome are related to karyotype, pubertal development and growth hormone treatment. Hum Reprod 2013;28:1899-907.

40. Ankarberg-Lindgren C, Kriström B, Norjavaara E. Physiological estrogen replacement therapy for puberty induction in girls: a clinical observational study. Horm Res Paediatr 2014;81:239-44.

41. Quigley CA, Wan X, Garg S, Kowal K, Cutler GB Jr, Ross JL. Effects of low-dose estrogen replacement during childhood on pubertal development and gonadotropin concentrations in patients with Turner syndrome: results of a randomized, double-blind, placebo-controlled clinical trial. J Clin Endocrinol Metab 2014;99:E1754-64.

42. Gravholt $\mathrm{CH}$, Andersen NH, Conway GS, Dekkers OM, Geffner ME, Klein KO, et al. Clinical practice guidelines for the care of girls and women with Turner syndrome: proceedings from the 2016 Cincinnati International Turner Syndrome Meeting. Eur J Endocrinol 2017;177:G1-70.

43. Torres-Santiago L, Mericq V, Taboada M, Unanue N, Klein KO, Singh R, et al. Metabolic effects of oral versus transdermal $17 \beta$-estradiol $\left(\mathrm{E}_{2}\right)$ : a randomized clinical trial in girls with Turner syndrome. J Clin Endocrinol Metab 2013;98:2716-24.

44. Sweetland S, Beral V, Balkwill A, Liu B, Benson VS, Canonico M, et al. Venous thromboembolism risk in relation to use of different types of postmenopausal hormone therapy in a large prospective study. J Thromb Haemost 2012;10:2277-86.

45. Labarta JI, Moreno ML, López-Siguero JP, Luzuriaga C, Rica I, Sánchez-del Pozo J, et al. Individualised vs fixed dose of oral $17 \beta$-oestradiol for induction of puberty in girls with Turner syndrome: an open-randomised parallel trial. Eur J Endocrinol 2012;167:523-9.

46. Cleemann L, Holm K, Kobbernagel H, Kristensen B, Skouby SO, Jensen AK, et al. Dosage of estradiol, bone and body composition in Turner syndrome: a 5-year randomized controlled clinical trial. Eur J Endocrinol 2017;176:233-42.

47. Carel JC, Elie C, Ecosse E, Tauber M, Léger J, Cabrol S, et al. Self-esteem and social adjustment in young women with Turner syndrome--influence of pubertal management and sexuality: population-based cohort study. J Clin Endocrinol Metab 2006;91:2972-9.

48. Rosenfield RL, DiMeglio LA, Mauras N, Ross J, Shaw ND, Greeley SA, et al. Commentary: launch of a quality improvement network for evidence-based management of uncommon pediatric endocrine disorders: Turner syndrome as a prototype. J Clin Endocrinol Metab 2015;100:1234-6.

49. Gravholt CH, Juul S, Naeraa RW, Hansen J. Morbidity in Turner syndrome. J Clin Epidemiol 1998;51:147-58.

50. Hasle H, Olsen JH, Nielsen J, Hansen J, Friedrich U, Tommerup N. Occurrence of cancer in women with Turner syndrome. Br J Cancer 1996;73:1156-9.

51. Bannink EM, Raat H, Mulder PG, de Muinck KeizerSchrama SM. Quality of life after growth hormone therapy and induced puberty in women with Turner syndrome. J Pediatr 2006;148:95-101. 